\title{
Leadership: the quandary of Aboriginal societies in crises, $1788-1830$, and 1966
}

\section{Dennis Foley}

\section{Introduction}

The sound of a British officer's leather-soled boot crunching on Hawkesbury sandstone in January 1788 resonated with change in Indigenous Australian epistemologies forever. The British invasion brought a new form of 'science' to the Australian landscape. Western knowledge systems were to be the 'truth' without peer. ' The imposition of the British system resulted in a progressive elimination and near extermination of Indigenous Australian social systems, knowledge, governance, economy and education. ${ }^{2}$ Perhaps the most devastating aspect of this conquest was the social construction of race that placed Indigenous Australians in a scientifically inferior space. Indigenous people were seen as sub-human with no societal or scientific systems in place. ${ }^{3}$ Indigenous knowledge was reinterpreted through Western ethnocentric scientific discourse based on a language and an audience that was non-Indigenous. ${ }^{4}$ This resulted in many misunderstandings of Indigenous knowledge, including its links to power and leadership.

Leadership as understood by the British post-1788, particularly in the early years of the colony, are examined in this paper. The factors that resulted in some Indigenous leaders' emergence from societal chaos and the need for military reaction are also examined. This includes discussion of the leaders Pemulwuy, Mosquito and Windradyne. The illegitimate imposition of leadership by the British on Bungaree will then be examined, to show that chiefdom status was often a term of convenience imposed by the coloniser. This is followed by discussion of Mr Vincent Lingiari, reviewing the circumstances that resulted in his emergence as an internationally recognised Indigenous Australian leader.

\section{The construction of knowledge in the late eighteenth century}

It is important to understand that several of the British officers in the First Fleet and subsequent garrison reinforcements had seen active service in the French-American War and the American War of Independence. For example, the background military service of some of the early British invading forces included: 
- Captain John Hunter was at the siege of Quebec;

- Captain Watkin Tench spent three months as a prisoner in Maryland;

- Lieutenant William Dawes was wounded in action against the French at Chesapeake Bay;

- Judge Advocate David Collins served in Nova Scotia and was at the Battle of Bunker Hill;

- Lieutenant Gidley King and Major Robert Ross were at Quebec and later captured by the French; ${ }^{5}$ and

- Governor Lachlan Macquarie, who assumed office as the fifth Governor of the colony on 28 December 1809, had seen active service as a lieutenant in the American War of Independence. ${ }^{6}$

This frontier experience on the eastern seaboard of North America provided these officers with a simplistic model of First Nations people. Having seen Native Americans and their tribal system of chiefs, they assumed that the Port Jackson clans were similar. They often referred to the Indigenous Australians as Indians. ${ }^{7}$

The subsequent appointment of Aboriginal 'chiefs' by Governor Macquarie altered the dynamics of an already fragile and fractured Indigenous society within the Sydney environs in 1815-16. ${ }^{8}$ The Eora society had already been decimated by smallpox, venereal disease and a protracted guerrilla war of attrition as the colony spread into Aboriginal pastures and fisheries, depriving them of food and disrupting what had been a stable co-existence within the landscape. ${ }^{9}$ The misinterpretation of the concept of a chief, or kingship, blinded the invaders to an understanding of the pluralistic societies of Indigenous Australia. A possible exception was Lieutenant William Dawes whose relationship with a young Indigenous woman, Patyegarang, enabled him not only to grasp the Eora languages, but it seems from his journals that he may also have obtained an insight into the Eora societal structure. ${ }^{10}$ Apart from Dawes, within the Western scientific knowledge system there was little debate over the preconceived idea of the supremacy of normal science in the identification and determination of legitimate knowledge. Indigenous Australia was not granted any legitimacy. ${ }^{11}$

The pluralistic style of society of Aboriginal Australia was an unknown concept to the invader. In their ignorance, the British could only determine chiefdoms. Subconsciously or consciously this system imposed a male-dominated class system over the once peaceful, homologous matrilineal Eora, which includes (but is not limited to) Wangle, Cadigal, Gai-mariagal, Gur-ing-gah, Bidgingal, Wallumattagal, Burramattagal and Darug clans. ${ }^{12}$ The acceptance of a male-dominated class system is based on an incorrect assumption that has been retained by several generations of Australian-born descendants of the British invaders.

Accustomed to Native America, the British also incorrectly assumed that the major social divisions were tribes, ${ }^{13}$ with a tribe considered to be a group of 
people under a recognised chief. Anthropologist Ronald Berndt has said 'most of us have become so used to speaking of Australian aboriginal tribes that we have rarely paused to examine their composition or the appropriateness of such a term'. ${ }^{14}$

The Eora pre-1788 was a society devoid of individuals seeking status, revenge or capital gains, as these were negative personal attributes not tolerated in the Elders circle. ${ }^{15}$ It was a pluralist society that did not experience dominance and leadership in the Western sense. While I accept that some group members had greater powers and rights than others, these differences were due to seniority of age and knowledge such as that gained though initiation, for example. ${ }^{16}$

An Indigenous academic, I am not a member of a tribe, I belong to a clan. Through my mother, I am a member of a matrilineal clan, the Gai-mariagal people of the Guringah language group. My matrilineal land is that country which is now called the northern suburbs of Sydney. I will use several oral history references from them. My father is of Wiradjuri, Capertee/Turon River clan descent, which is also a rich oral history resource that I use in this paper. Critics of this paper in its draft form stated that oral histories and family viewpoints do not add to overall knowledge. The denial of oral history when compared to history from the pen of an English military person, or the primary records of a missionary, a police officer or public servant reinforces the Eurocentric concept that 'knowledge is power, or power is knowledge' ${ }^{17}$ — as long as you are white, protestant and a male, especially in the early days of the colony. It is widely accepted that oral history is fragmented, and that the knowledge that has been retained is subject to societal destruction. This means that Indigenous scholars are forced to confirm their history only from within modernity's biased written record. This is a transgressive step away from acknowledging the implications of oral history and the substantiation of Indigenous epistemologies. The role of Indigenous Australian narrative discourse 'plays a decisive role ... [in] personal and social identity as well as in the transmission of cultural knowledge'. ${ }^{18}$ Indigenous oral history is a legitimate reference for the recipients of such knowledge within their own clan.

From this inheritance, I am asserting that Australia has an Aboriginal history, a history that allows Indigenous epistemological practices.

\section{Aboriginal society pre-contact}

What were the social constructs of power like in the Eora clans pre-contact? Aboriginal society in the late eighteenth and early nineteenth century within the Eora and Gai-mariagal people are discussed in the following section.

The English described the Eora as a stubborn and proud people that were unwilling to conform to habits that the Europeans wished to enforce, such as the wearing of clothes and adopting a settled life. ${ }^{19}$ We were proud and 
stubborn, we still are. What was considered a 'settled life' pre-1788 and how did this relate to Indigenous social construction? In British eyes a 'settled life' was a rural economy with surplus production. They had no understanding of the already existing structured 'settled life' of the Eora pre-1788. They failed to see the existing demographic patterns or land-use management practices and social constructs. Geoffrey Blainey reminds us of the contrasts that could be made regarding British concepts of civility:

If an Aborigine in the seventeenth century had been captured as a curiosity and taken in a Dutch ship to Europe, and if he had traveled all the way from Scotland to the Caucasus and had seen how the average European struggled to make a living, he might have said to himself that he had seen the third world and all its poverty and hardship. ${ }^{20}$

Blainey shows Europe interpreted as a possible land of 'savages'. In contrast, prior to European invasion, the Eora lifestyle was complex, based within a matrilineal society. ${ }^{21}$ Senior men sat in ceremony (both within Gai-mariagal Guringah and other east coast clans) to decide important issues. Due to their age and status they enjoyed a level of power and prestige. ${ }^{22}$ Not all men were in this body that is generally called 'Elders'. Admittance was restricted to the most intelligent, diligent and, some would suggest, conformist over the long period of learning the ceremony and sacred knowledge of the clan. Kinship and tradition were the strengths that bound senior men who enforced a strict system of law. Likewise women also gained power, knowledge and prestige. Those of strong character were never outmatched by their gender equivalents as women also had a key role in the application of Indigenous law and resultant leadership functions within the clan. ${ }^{23}$

In contrast to the invading settler society, the Eora had an intimate relationship with nature and a non-materialistic philosophy. This is reinforced in oral history, through which we were instructed on the management of the wetlands, the abundance of foodstuffs in seasonal periods at what is now Queenscliff, Curl Curl and the Dee Why lagoons. We learnt how the oyster was harvested, the mullet caught in nets, the fat fish taken on line, the larger fish taken on burley and speared off the rocks, how the turtle was a feast in late summer, and similar stories of winter of the fat possum, the echidna, the fruit bat, the wallaby and kangaroo. Our calendar was based on the development of the family, when a child could be born, when food was available, when it was time to live on the coast, to eat shellfish, or when it was cooler and time to move inland. Pre-1788 this was a civil, settled culture that was 'admirable'. ${ }^{24}$

\section{Leadership}

Koori concepts of consciousness and responsibility demand that the responsibility for managing relationships is taken by all parts of the kinship system, to differing 
degrees, because all of the parts regulate each other. Deborah Rose reached a similar understanding in the Victoria River District of the Northern Territory. ${ }^{25}$ Leadership in the singular did not exist; it was actually stratified through various senior clan members. The concept of 'a leader' within Koori society is misunderstood in some oral histories, in much anthropology and within colonial and later history.

\section{Aboriginal leaders}

One individual, Pemulwuy (Pim-el-wi) ${ }^{26}$ has been recorded as a leader of the Bidjigal $^{27}$ people of Botany Bay and the Georges River, and a leader the Eora wars of 1790 to 1802 . Another felon wanted by the British during this same period was Musquito of the Hawkesbury clans who was captured and exiled to Norfolk Island in July 1805 for raids on settlers' properties in the Hawkesbury and Georges River districts. Later he gained notoriety for his alleged leadership of the wild Oyster Bay tribe in Tasmania. ${ }^{28}$

Both Pemulwuy and Musquito were seen by the colonialists to be Aboriginal leaders. It is debatable whether their leadership in guerrilla warfare legitimately arose from a clan Elder consultative process. Rather their leadership may have been the result of their personal aspirations. Or perhaps they became military leaders out of the desperate necessity to survive following the destruction of Eora society after the 1789 smallpox epidemic? Were these men forced to take on a transgressive role and become leaders in a manner which went against their societal values, bearing in mind that their constructs of law and land management were also destroyed through the colony's greed for land? Perhaps an answer is to be found in the rise in 1824 of another Indigenous guerrilla fighter, Windradyne, discussed below. ${ }^{29}$ First I will look at a contrast to Pemulwuy and Musquito, a non-military leader, Bungaree, who was the first proclaimed Aboriginal 'chief'.

\section{Bungaree, chief of the Sydney Blacks}

If some of my comments that follow appear insolent towards Bungaree, I apologise, out of respect to his descendants, members of the Guringah Tribal Link, an incorporated Aboriginal group. They, like my mother's family, have connection to the 'Broken Bay' clans of which Bungaree is a member. Bungaree was a victim of colonisation. No blame should be attached for what he did, however we as Indigenous people should learn from illegitimate leadership, for when it is imposed on us, it can, as in Bungaree's situation, have negative outcomes for Indigenous Australians in general.

Bungaree gained notoriety for many reasons, but it is his attainment of a gorget as a mark of status that is of concern to me here. Governor Macquarie, in a naïve attempt to break Indigenous Australians of their nomadic ways, proclaimed 
Bungaree as the Chief of the Broken Bay tribes on 31 January 1815 in a rather flamboyant ceremony. He further proposed that 16 adults would settle on a farm with huts, a boat, supplies and convict labourers. ${ }^{30}$ Bungaree was issued with a king plate or gorget. This has its origin as a part of armour worn by a medieval knight. It protected the neck. ${ }^{31}$ In Australia at that time officers of the marine infantry wore them as a part of their uniform. ${ }^{32}$ Both the French and the English had used gorgets as gifts to Native American chiefs and warriors since the American war of 1755-62. The British and the Americans often recognised chiefs by the gorgets or they were seen as a gift to an ally. ${ }^{33}$

Early Russian explorers to Australia observed that the British colonial government manipulated Indigenous people into positions of dominance assisted by the use of gorgets, bypassing leadership choices made by the Indigenous community. For example, Novosil'sky noted that 'the English Government itself selects the elders' ${ }^{34}$ By conferring the distinction of chief as in Bungaree's case, Governor Macquarie made official a status that was usually based on an Aboriginal person's individual loyalty and how useful they could be to the colonialist. ${ }^{35}$ From the Indigenous perspective, some say that Bungaree was nothing more than a puppet for Macquarie even though he had previously been described as a 'worthy and brave fellow' by Matthew Flinders. He was also was given a glowing character reference by Lieutenant Menzies in a letter to Governor King in July 1804 with respect to Bungaree's skill 'as an intermediary between blacks and whites' ${ }^{36}$

For Bungaree, kingship allowed him to establish himself as an important identity on his own terms, using Macquarie's gifts. These suited his lifestyle, now a mix of Indigenous and Western. ${ }^{37}$ He attempted to transgress both of these. His entrepreneurial skills were exhibited when he realised that the British had degraded the land prohibiting traditional land-use practices, so he utilised the convict help. For several years the peaches that he produced from his farm provided him with a steady income. ${ }^{38}$ Sadly this income appears to have been squandered mostly on alcohol, as were the proceeds of the sale of most of the Governor's gifts, including a much-treasured fishing boat.

Bungaree was the first chief appointed in Australia, issued with a gorget. This became a practice implemented across the frontier. Evidence suggests that pastoralists even encouraged the inheritance of titles from father to son to maintain control and respect for the title amongst the Indigenous group. ${ }^{39}$ Aboriginal groups would later spurn this tacky chestplate regalia that was associated with the British system. ${ }^{40}$ By the end of the nineteenth century, following the widespread collapse of Indigenous economic and cultural bases in southern and eastern Australia, 'king plates' had no meaning and became museum pieces. ${ }^{41}$ Bungaree's influence as an illegitimate leader dissipated, as did his assets; in time even his gorget disappeared. In 1824 a new Indigenous 
leader appeared on the western plains west of Sydney town. However this leader did not grace the Governor's pleasure.

\section{Windradyne of the Wiradjuri}

Following the 'discovery' of the established Indigenous trading route over the Blue Mountains by Blaxland, Wentworth and Lawson in 1813, after they were shown the way by their two Darug guides, ${ }^{42}$ the lands of the western plains were soon invaded by graziers looking for pastures for their sheep. By 1824 the white population had increased to 1267 people with 91,636 acres cleared and fenced, and 113,973 sheep and cattle by $1825 .{ }^{43}$ The traditional lands of the Wiradjuri were being consumed by aggressive landowners, including John Oxley and John Macarthur, 'who were devouring land with the obsessiveness of obese gluttons'. 44

Frustrated at the destruction of sacred areas, the removal of possum and kangaroo habitat which formed a staple of their diets, the Wiradjuri were forced to kill settler livestock for food. The retaliation was swift; Windradyne was captured by Major Morisset and kept in leg irons for a month, to teach him a lesson. It had the opposite effect. Within a short period after his release he witnessed members of his family murdered by whites and within days he formed an efficient group of warriors using guerrilla tactics. He attacked isolated farming huts, beginning with a hut that when built had desecrated a sacred site used in male initiation, according to local oral tradition. ${ }^{45}$ The pastoral industry had destroyed a site vital to sustaining Indigenous knowledge systems.

Windradyne's actions seem justified to an extent. But the declaration of martial law that followed was used to justify atrocities and massacre of the Wiradjuri people. It was an extreme over-reaction encouraged by absentee landowners who lived in Sydney and could not keep farm staff employed due to fear of the Wiradjuri. $^{46}$ Brigadier General Sir Thomas Brisbane (Governor Macquarie's replacement) is still held accountable by the Wiradjuri for the slaughter of their people $^{47}$ in an all-out war from October 1823 to 11 December 1824 which reached a peak of destruction following Brisbane's proclamation of martial law on 14 August $1824 .^{48}$

\section{Irish-Aboriginal oral history}

A discussion of the link between oral history and written history with respect to my own background is relevant here.

Two of the sons of the former convict Samuel Foley were working as farm hands and shepherds in the Turon River district north of Bathurst at the height of the Wiradjuri wars. As the sons of Irish Catholics they had a sympathetic association with wanton destruction and indiscriminate murder of innocent souls, as their forefathers had suffered similar fates as the result of persecution, greed and 
murder at the hands of the British nobility and military in the conquest of Ireland. It is said that they showed respect and compassion to the Wiradjuri and were recorded by some as being kind to the Indigenous groups. For this they were spared and were treated with respect by the Wiradjuri, in a manner similar to the treatment of the settler Suttor. ${ }^{49}$ They witnessed either directly or indirectly the possible massacres at Billiwillinga and Bells Falls Gorge ${ }^{50}$ (or incidents nearby). In the chaos that followed they provided shelter for two young women and a small child. Several other children that they tried to defend and hide were 'sliced to pieces' by the mounted soldiers. ${ }^{51}$

As mentioned previously, a shared 'hatred' of the English existed between the sons of Irish Catholics and the Wiradjuri. One of these men was Thomas Foley, who was the author's grandfather's great-grandfather. At the end of the Wiradjuri wars he married one of the young women that he protected, who was later baptised as Mary. Their union was officiated in the fledgling Catholic Church at Parramatta. Their great-grandson was born at Tingha and was baptised as Johannes Foley, known to the Koori families in Glebe in the 1920s and 1930s as 'Jack', or 'John'. He spent a short period on the Tingha Mission as a child whereupon he joined up with his father and travelled on his dray and wagon, supplying the highland traders and the burgeoning towns of Inverell and Glenn Innes with freight from the steamer ports on the coast.

This oral history and knowledge was passed down through my family, from my grandfather to my father and my father's brothers. ${ }^{52}$ The wanton slaughter of the Wiradjuri became 'real' in the family history and in some ways mirrored the Irish oral history. They were both indigenous to their sovereign states; from island nations; they were both brutally colonised by the British and they both had their leaders. In my family's oral histories, the details of the Irish atrocities have been forgotten with time, it is the Wiradjuri accomplishments on the battlefield and Windradyne's leadership that has been remembered and retold generation after generation. ${ }^{53}$

After two months of massacres the Wiradjuri were a spent force with no reserves to continue the military struggle. Windradyne and what was left of his family, together with other survivors of the massacres, travelled over the mountains to Parramatta and surrendered to Governor Brisbane. He lived for another decade in peace and was widely referred to as a 'chief', 'a great leader of his people'. ${ }^{54}$ Born into a pluralist society he witnessed the destruction and extermination of his Elder system. The loss of male Elders in a patrilineal society broke down any consultative and communally acceptable decision-making process. Windradyne, in a most uncharacteristic Indigenous mode, initially took control of a fighting force out of anger, hate or reprisal for the murder of family and loss of traditional lands. ${ }^{55}$ The precise trigger for his actions is unknown. 
Windradyne exhibited those leadership qualities that Larson has defined in contemporary management literature as including creativity, inspiration, entrepreneurship and achieving a shared sense of commitment from his followers. ${ }^{56}$ Windradyne was described on his surrender as one of the finest looking natives ever seen, as 'noble'. 57 No doubt he was a charismatic leader who came to fame as a result of the chaos of colonisation, in a similar way perhaps to Pemulwuy and later Musquito.

After Windradyne's surrender he was allowed to live in peace and was subsequently used by the colonial powers to assist them in the pastoral settlement of the western plains of New South Wales. He then became a leader whose power was illegitimate within his social order, categorised as a chief by the colonial government. He lived out his days as a token of what he had once been. He is a warrior without Elders, a clan leader without a clan, a 'chief' without land or a people. The Bathurst District Historical Society erected a plaque on his grave in 1954 that calls him the last Chief of the Aboriginals, a friend to the settlers, a true patriot. ${ }^{58}$ Perhaps this is how history wishes to recall him in his last years, but is it as a true patriot to the colonial conquest of settlement and subsequent stealing of land, or a patriot to the Aboriginal cause? Either way he died of injuries suffered following a fight with another Indigenous person. ${ }^{59}$ It appears his chiefly status was not universally recognised as superiority by all people.

With Windradyne's surrender it seems he became a chief in name only. Pemulwuy and Mosquito's military-like leadership status ended with their executions. In comparison, was Bungaree ever a leader or a 'chief' of his people? Western constructs of leadership resulted in the demise of all four of these individual examples of Indigenous leadership. These men would most certainly been cut off from their spiritual realms of knowledge within the circles of Elder knowledge. This would have occurred following population attrition by musket, smallpox and colonial-derived diseases. The leadership actions in military pursuits by Pemulwuy, Musquito and Windradyne took them away from family groups. This ensured that they were also unable to pass on their knowledge to their youth, as those that they associated with were inevitably killed. Leadership born from military chaos proved to be a negative attribute in the circles of their Indigenous society. The structure of Indigenous society in general made the formation of significant fighting forces almost impossible, as most groups remained small and semi-autonomous, except for periods such as the Eora mullet feast, ${ }^{60}$ or other important non-aggressive ceremonies. ${ }^{61}$ Clans rarely exceeded 60 people and, for the most part, Indigenous Australian gatherings pre-contact were peaceful. The dimensions of social behaviour that would provoke aggressive responses involving arguments over territory, ideology and rule by minorities were not issues normally tolerated within Aboriginal society. ${ }^{62}$ Within our oral history we talk of the warriors Barnoo and the man who became the water 
dragon. Both of these individuals were soldiers in unknown battles, which is contradictory to a peaceful society. Like them, Pemulwuy, Mosquito and Windradyne appear as aggressors within their social construct. Bungaree was a political appointment with limited leadership influence.

By the end of the nineteenth century, the concept of leadership had gone full circle. Aboriginal people knew whether a person was a good choice for a chief or a king. Individuals were bestowed with a title or obtained one through coercive tactics, even when sanctions by non-Aboriginal authority figures no longer had any influence. ${ }^{63}$ The demise of the gorget saw the rise of contemporary Indigenous leaders beginning in the early years of the twentieth century.

\section{Contemporary leadership}

The social turmoil of government-driven assimilation policies of the twentieth century, together with the stifling negative racial attitudes of over 200 years of colonial and post-colonial domination has had a major effect on Indigenous social structure. Indigenous Australians, however, have continued to learn and develop, within an oppressive struggle for the right to control their identity as a people, to determine political status, and pursue economic, social and cultural development. ${ }^{64}$ The struggles of Pemulwuy, Musquito and Windradyne were no different, except that they used spears in addition to the tools of the modern leader, including diplomacy, tact and utilisation of the media to influence public opinion.

Numerous leaders have arisen; many have faded into obscurity. For many, if not most, gone are the traditional circles of Elder knowledge, men of high esteem. ${ }^{65}$ In their place are contemporary people whose values are, arguably, still governed by Indigenous kinship and respect. However some of the new leaders are different. One outstanding contemporary leader never relinquished or compromised his 'high degree' status, recognised under Indigenous law. ${ }^{66}$ He maintained his 'traditional beliefs' yet was able to transgress with his leadership qualities into the settler society of contemporary Australia. That outstanding leader is Mr Vincent Lingiari who, in the words of Sir William Deane, is without a doubt 'one of the greatest Aboriginal leaders' ${ }^{67} \mathrm{He}$ has a dual role in modern leadership terminology, as a Kadijeri, a man in charge of secret and male ceremony, ${ }^{68}$ that some would call a traditional law man, yet he is no less a leader of his people within the modern definition. ${ }^{69}$

Lingiari was illiterate in the European context in that he could neither read nor write and his English vocabulary was limited, yet 'he possessed great eloquence even in English'.70 Softly spoken, he displayed an unwavering will to obtain his people's rights to their traditional lands. ${ }^{71}$ Lingiari fought against assimilation and cultural extirpation. He had the knowledge of his people's creation at Seale 
Gorge, near Wattie Creek, Northern Territory. He led a seven year long struggle, initially against a large British-owned pastoral company and then the Australian government. This had two significant outcomes. Firstly, he achieved the support of the North Australian Workers Union, which subsequently successfully filed an application with the Conciliation and Arbitration Commission seeking equal pay for Aboriginal workers. ${ }^{72}$ Secondly, in 1986, the Gurindji people, with professional support, obtained inalienable freehold title to Daruragu, a part of their traditional lands. In an emotional ceremony in 1975, the Prime Minister Gough Whitlam poured sand into the outstretched hand of Vincent Lingiari. This remains an iconic image of the potential of reconciliation in Australia. ${ }^{73}$

When you reflect on Lingiari's life, his courage, charisma, strong leadership, vision, moral fortitude and ability to maintain solidarity amongst his people, these are personal qualities that all Australians can aspire to. A leader not just for his kin relations, Mr Lingiari is a leader for all Aboriginal people. In fact, his attributes are such that he is a role model for all Australians to aspire to; his is legitimate leadership.

\section{Conclusion}

Self-endowed leadership or a title such as king or chief has achieved little within Indigenous Australian society. I have argued that 'kingplates' were normally sanctioned where the coloniser could obtain profit from interaction with the imposed title. On the other hand the warrior leaders, driven by revenge or need for survival, were victims of technological superiority of the British fighting forces. The spear and boomerang were no match for the rifle. ${ }^{74}$

Aboriginal Australia has changed irreversibly since that leather boot of a British officer first crunched on Hawkesbury sandstone so many years ago. In this paper, case studies from the writer's kin connections, and a notable leader from Central Australia provide a personal approach to history and to the concepts of knowledge that are linked to Aboriginal leadership. Historically, the interactions involved violence. In contemporary times, leaders who walk within the worlds of black and white and preserve their Aboriginality are strong role models, as shown by Mr Lingiari. The ability to transgress between the two worlds ensures that Indigenous Australians do not remain frozen within a single past timeframe.

This paper has given the reader an insight into the division that Indigenous leaders experience in the struggle to retain, respect and maintain Indigenous knowledge systems and overcome prejudice within an oppressive political environment, be it in 1788 or 1966. Mosquito, Pemulwuy and Windradyne tried to do so with guerrilla military tactics. Bungaree was the symbolic leader with kingship bestowed on him by a Governor who did not understand the structures of Indigenous cultures. His was a title of convenience. Mr Lingiari, with his noble yet modest defiance and charisma, captured the hearts and minds of 
unionists, politicians, the legal and medical professions and large groups of the Australian public. All things being equal, and not discounting the strong support mechanisms that were vital to the 1967 referendum campaign, if Mr Lingiari had not shown such strong leadership and captured the imagination of the Australian press and public, would the pro-Indigenous questions have won the referendum so convincingly in 1967? History has shown effective legitimate leadership can produce positive outcomes for Australian society. Such is the transgressive potential of the Indigenous leader.

\section{References}

\section{Primary sources}

Budby, John 2004, Personal Interview, Brisbane, 8 March 2004.

Hobart Town and Van Dieman's Land Gazette, Hobart.

\section{Secondary sources}

Altman, JC and Hunter, BH 2003, Monitoring 'practical' reconciliation: evidence from the reconciliation decade, 1991-2001, Discussion Paper No. 254/2003, Centre for Aboriginal Economic Policy Research, The Australian National University, Canberra.

Attenbrow, Val 2002, Sydney's Aboriginal past, University of New South Wales Press, Sydney.

Barratt, Glynn 1981, The Russians at Port Jackson: 1814-1822, Australian Institute of Aboriginal Studies, Canberra.

Bell, D 1987, 'Aboriginal women and the religious experience', in WH Edwards (ed.), Traditional Aboriginal society, Macmillan Education Australia Pty Ltd, Melbourne.

Bern, J 1979, 'Politics in the conduct of a secret male ceremony', Journal of Anthropological Research 35(1).

Berndt, C 1950, Women's changing ceremonies in Northern Australia, Hermann, Paris.

Berndt, RM 1959, The Concept of 'The Tribe' in the Western Desert of Australia, Oceania, 30(2): 81-107.

Blainey, G 1982, Triumph of the Nomads: a history of ancient Australia, Macmillan, South Melbourne.

Broome, Richard 1994, Aboriginal Australians, 2nd edn, Allen and Unwin, St Leonards. 
Budby, John 2001, 'The academic quandary - an Aboriginal experience', Postgraduate Research Supervision: Transforming (R)Elations, in the series Eruptions: New Feminism Across the Disciplines, Alison Bartlett and Gina Mercer (eds), Peter Lang Publishing, New York.

Coe, Mary 1989, Windradyne: a Wiradjuri Koorie, Blackbooks, Glebe.

Concise Oxford Dictionary 1976, 'tribe', Claredon Press, Oxford.

Deane, William 1996, 'Some signposts from Daguragu', The Inaugural Vincent

Lingiari Memorial Lecture, Northern Territory University, August,

Council for Aboriginal Reconciliation, Kingston, ACT.

Dodson, Michael 2003, 'The end in the beginning: re(de)finding Aboriginality', in Michele Grossman (coordinating editor), Blacklines. Contemporary Critical Writing by Indigenous Australians, Melbourne University Press, Melbourne.

Elder, Bruce 1992, Blood on the wattle: massacres and maltreatment of Australian Aborigines since 1788, National Book Publishers, Brookvale.

Elkin, AP 1977, Aboriginal men of high degree. Initiation and sorcery in the world's oldest tradition, Inner Traditions, Rochester, Vermont.

Flannery, Tim (ed.) 1999, The birth of Sydney, Text Publishing, Melbourne.

Foley, Dennis 2001, Repossession of our spirit: the traditional owners of northern Sydney, Aboriginal History Inc, Canberra.

- 2002, 'An Indigenous standpoint theory', Journal of Australian Indigenous Issues 5(3): 3-13.

Grossman, M (coordinating editor) 2003, Blacklines: contemporary critical writing by Indigenous Australians, Melbourne University Press, Melbourne.

Hills, Matt 2005, How To Do Things With Cultural Theory. Hodder Education, London.

Klapproth, Danièle 2004, Narrative as social practice: Anglo-Western and Australian Aboriginal Oral Traditions, Mouton de Gruyter, Berlin and New York.

Lambert, John 2000, Brokers of cultural change, John Terence Lambert, Brisbane.

Larson, Paul 1999, 'A look at leadership', Montana Business Quarterly 37(2): 1821.

Marshall, PD 2004, Celebrity and Power: Fame in Contemporary Culture, University of Minnesota Press, Minneapolis and London.

Miller, James 1985, Koori - a will to win: the heroic resistance, survival and triumph of Black Australia, Angus \& Robertson, Sydney.

Mulvaney, John and Kamminga, Johan 1999, Prehistory of Australia, Smithsonian Institution Press, Washington. 
Neal, David 1987, 'Free society, penal colony, slave society, prison?' Historical Studies 22(89): 497-518.

Neill, Rosemary 2002, White out: how politics is killing Black Australia, Allen and Unwin, St Leonards.

Rigney, Lester-Irabinna 1997, 'Internalisation of an Indigenous Anti-Colonial cultural critique of research methodologies: A Guide to Indigenous Research Methodologies and its principles', Journal of American Studies 14(2): 109-122.

1999, 'The first perspective: culturally safe research practices on or with Indigenous Peoples', in 1999 Chacmool Conference Proceedings, University of Calgary, Alberta, Canada, 'Internationalisation of an Indigenous anticolonial cultural critique of research methodologies: A Guide to Indigenist research methodology and its principles', Higher Education Research and Development in Higher Education 20: 629-636.

2000, 'A first perspective of Indigenous Australian participation in science: framing Indigenous research towards Indigenous Australian intellectual sovereignty', A keynote address, Second National Indigenous Researches Forum, Aboriginal Research Institute University of South Australia, Adelaide.

_ 2001, 'A first perspective of Indigenous Australian participation in science: framing Indigenous research towards Indigenous Australian intellectual sovereignty', Kaurna Higher Education Journal 7: 1-13.

Rose, Deborah 1987, 'Consciousness and responsibility in an Australian Aboriginal religion', in WH Edwards (ed.), Traditional Aboriginal society, Macmillan Education Australia Pty Ltd, Melbourne.

Salisbury, T and Gresser, PJ 1971, Windradyne of the Wiradjuri: martial law at Bathurst in 1824, Wentworth Books, Sydney.

Sharp, Ian and Tatz, Colin 1966, Aborigines in the economy, Jacaranda Press, Brisbane.

Smith, Keith Vincent 1992, King Bungaree, Kangaroo Press, Kenthurst.

Stanner, W 1979, White man got no Dreaming, ANU Press, Canberra.

Tench, Watkin 1979, Sydney's first four years, Library of Australian History, Sydney.

Turbet, Peter 1989, The Aborigines of the Sydney District before 1788, Kangaroo Press, Kenthurst, NSW.

Troy, Jakelin 1993, King plates: a history of Aboriginal gorgets, Aboriginal Studies Press, Canberra. 
Vibe 2004, Celebrity Vibe: Vincent Lingiari, accessed 15 November 2006, <http://www.vibe.com.au/vibe/corporate/celebrity_vibe/showceleb.asp?id=372> Issue 90, August.

Weinstein, Jay and Stehr, Nico 1999, 'The power of knowledge: race science, race policy, and the Holocaust', Social Epistemology, 13(1): 3-35.

Willey, Keith 1979, When the sky fell down: the destruction of the tribes of the Sydney Region 1788-1850s, William Collins Pty Ltd, Sydney.

\section{ENDNOTES}

1 Rigney 2001: 3.

2 Rigney 2001: 4.

3 Rigney 1999: 636.

4 Rigney 2000: 1.

5 Smith 1992: 20.

6 Smith 1992: 73.

7 Tench 1979: 50.

8 Tench 1979: 77, 85.

9 Flannery 1999: 31; Willey 1979: 56-78.

10 Flannery 1999: 26-27, 111-115; Turbet 1989: 75-76.

11 Rigney 2000: 1-2.

12 Foley 2001: 7.

13 Mulvaney and Kamminga 1999: 75.

14 Berndt 1959: 26-29.

15 Lougher, C circa 1964. Clarice Lougher is my mother's mother, a woman of Koradji training and skill, a matriarch of the northern Eora, my mentor at birth and childhood.

16 Attenbrow 2002: 60.

17 Weinstein and Stehr 1999: 4.

18 Klapproth 2004: 47-48.

19 Flannery 1999: 22.

20 Blainey 1982: v-vi.

21 Foley 2001: 12.

22 Broome 1994: 20.

23 Broome 1994: 20.

24 Broome 1994: 26.

25 Rose 1987: 259.

26 Elder 1992: 19-20; Tench 1979: 206.

27 Turbet 1989: 22.

28 Hobart Town and Van Dieman's Land Gazette, 26 March 1824: 2. See also Chapter 7 this volume.

29 Elder 1992: 47.

30 Smith 1992: 77.

31 Troy 1993: 2.

32 Troy 1993: 2.

33 Troy 1993: 5.

34 Navosil'sky 1820 cited in Barratt 1981: 29.

35 Troy 1993: 6-7.

36 Smith 1992: 68-71.

37 Troy 1993: 13. 
38 Troy 1993: 13.

39 Troy 1993: 41.

40 Troy 1993: 13.

41 Troy 1993: 40

42 Troy 1993: 42.

43 Troy 1993: 45.

44 Elder 1992: 45.

45 Elder 1992: 48.

46 Elder 1992: 51.

47 Coe 1989: 52-53.

48 Elder 1992: 51.

49 Salisbury and Gresser 1971: 12.

50 Elder 1992: 51.

51 Jack Gordon and Leo Foley (brothers), family communication 1964-1970.

52 Foley family communication 1964-1970.

53 Foley, Gordon, personal communication 1964-1974. The rise of the 'Kelly Gang' (which included the Foley siblings and other Koori adolescents) in the back lanes of Glebe during the Great Depression of 1929-32 no doubt helped to ensure that the defence of their 'turf' contained a mixture of Irish and Wiradjuri folklore. The Catholic Kooris maintained a struggle against Protestant whites of the surrounding estates in Sydney's working class areas (Gordon, Jack and Leo Foley, family communication 1964-1970).

54 Elder 1992: 49-53.

55 Coe 1989: 37.

56 Larson 1999: 18-21.

57 Sydney Gazette 30 December 1824, cited in Coe 1989: 37.

58 Coe 1989: 83.

59 Coe 1989: 64.

60 Foley 2001: 106-6.

61 Turbet 1989: 24-27.

62 Elder 1992: 198.

63 Troy 1993: 41.

64 Dodson 2003: 31.

65 Troy 1993: 14.

66 Elkin 1977: 3-15.

67 Deane 1996: 7.

68 Deane 1996: 7.

69 Smith 1992: 20.

70 Smith 1992: 7.

71 Vibe 2004: 1.

72 Deane 1996: 4.

73 Mr Lingiari showed respect to Anglo-Australia by subsequently pouring the sand through the Prime Minister's hand.

74 Broome 1994. 